\title{
Gayrimenkul Yatırım Ortaklıklarının Piyasa Yapısı ve Yoğunlaşma Düzeylerinin Analizi: Borsa İstanbul'dan Kanitlar
}

Mehmet Apana,

\section{Özet}

$\mathrm{Bu}$ çalışmada, Türkiye'deki Gayrimenkul Yatırım Ortaklıkları (GYO)'nın piyasa yapısı ve yoğunlaşma düzeyleri; N-Yoğunlaşma Oranı (CR4 ve $\left.\mathrm{CR}_{8}\right)$ ve Herfindahl-Hirschman (HHI) Endeksi ile analiz edilmiştir. Çalışmanın veri seti, 2007-2018 dönemini kapsamaktadır. GYO'ların CR4 yoğunlaşma oranına göre 2007 yılında \%81,29 ile en yüksek değer, 2018 yılında ise \%57,62 ile en düşük değer aldığı tespit edilmiştir. Diğer yandan GYO'ların CR8 yoğunlaşma oranına göre 2007 yılında \%96,00 ile en yüksek değer, 2016 yılında ise \%73,11 ile en düşük değer aldığı tespit edilmiştir. Ayrıca GYO'ların yoğunlaşma düzeyi, HHI analiz sonucuna göre 2010 yılında en yüksek değer 2297 ve 2018 yılında 1272 en düşük değeri aldığı tespit edilmiştir. 2012 yılından sonra yoğunlaşma oranları $\left(\mathrm{CR}_{4}, \mathrm{CR}_{8}\right)$ ve $\mathrm{HHI}$ endeks değerleri ile $\mathrm{GYO}$ sayıları arasında negatif bir ilişki olduğu tespit edilmiştir. GYO sektöründe 2007-2011 döneminde monopol piyasa, 2012-2018 döneminde ise oligopol bir piyasa yapısının olduğu tespit edilmiştir.
Anahtar Kelimeler

Gayrimenkul Yatırım Ortaklığı

$\mathrm{N}$-Yoğunlaşma Oranı $\left(\mathrm{CR}_{4}, \mathrm{CR}_{8}\right)$

Herfindahl-Hirschman Endeksi

Borsa İstanbul

Makale Hakkında

Geliş Tarihi: 25.07.2019

Kabul Tarihi: 24.04 .2020

Doi: 10.18026/cbayarsos.596856

\section{Analysis of Market Structure and Concentration Levels of Real Estate Investment Trusts: Evidence From Borsa İstanbul}

\begin{abstract}
In this study, Real Estate Investment Trusts (REITs) in Turkey market structure and concentration levels, it was analyzed by $\mathrm{N}$-Concentration Ratio $\left(\mathrm{CR}_{4}\right.$ and $\mathrm{CR}_{8}$ ) and Herfindahl-Hirschman (HHI) Index. The data set of the study covers the 2007-2018 period. According to $\mathrm{CR}_{4}$ concentration ratio, REITs had the highest value with $81.29 \%$ in 2007 and lowest value with $57.62 \%$ in 2018 . On the other hand, according to $\mathrm{CR}_{8}$ concentration ratio, REITs had the highest value with $96.00 \%$ in 2007 and lowest value with $73.11 \%$ in 2016. In addition, according to the HHI analysis, the concentration level of REITs was found to be 2297 in 2010 and 1272 in 2018. After 2012, there was a negative relationship between concentration ratios $\left(\mathrm{CR}_{4}, \mathrm{CR}_{8}\right)$ and $\mathrm{HHI}$ index values and REIT numbers. In the REIT sector, it was found that there was a monopoly market in 2007-2011 period and an oligopoly market structure in 2012-2018 period.
\end{abstract}

Keywords

Real Estate Investment Trust

$\mathrm{N}$-Concentration Ratio $\left(\mathrm{CR}_{4}\right.$,

Herfindahl-Hirschman Index

Borsa İstanbul

\begin{tabular}{r} 
About Article \\
\hline Received: 25.07 .2019 \\
Accepted: 24.04 .2020 \\
Doi: $10.18026 /$ cbayarsos 596856
\end{tabular}

Doi: 10.18026/cbayarsos.596856

a İletişim: mehmetapan@karabuk.edu.tr

b Dr. Öğretim Üyesi, Karabük Üniversitesi İşletme Fakültesi / Demirçelik Kampüsü Kardemir Blok A Girişi, Kat:2 78050 KARABÜK ORCID: 0000-0001-9471-4810. 


\section{Giriş}

Finansal piyasaların gelişmesi ile beraber yatırım araçları ve finansman alternatifleri de artmaktadır. Bu çerçevede gayrimenkul sektöründe Gayrimenkul Yatırım Ortaklıkları (GYO), en önemli kurumsal yatırımcılardan birisidir. GYO'lar, ilk defa 1961 yılında Amerika Birleşik Devletleri'nin (ABD) Massachusetts eyaletinde faaliyete geçmiştir. Türkiye'de ise GYO'lar, 1995 yılındaki yasal düzenleme ile faaliyete geçmiştir. 1997 yılında ise GYO'ların hisse senetleri, Borsa İstanbul'da işlem görmeye başlamıştır. GYO'ların temel görevi; gayrimenkul sektörünün finansman ihtiyacını karşılama ve piyasaya şeffaflık kazandırmaktı. Ancak GYO'lar, büyük ölçekli gayrimenkul projelerinin hayata geçirilebilmesini sağlayan önemli bir sermaye piyasası kurumu haline gelmiştir (Kandır \& Özhan, 2018:32). Halen Dünya genelinde 36 ülkede GYO uygulaması bulunmaktadır. Küresel yatırım fonları, yüksek getiri hedefi ile portföylerinde en çok GYO'lara yer vermektedir (Dalkılıç \& Aşkın, 2018:70).

Türkiye' deki GYO'lar; 1997 yılında 2 adet olarak faaliyete başlamış, daha sonra bu sayı ancak 2005 yılında 9'a ulaşmıştır. GYO sayısı 2006 yılında 11, 2011 yılında 21 ve 2013 yılında 30 ve 2018 yılında ise 33'e çıkmıştır. 1997-2018 döneminde GYO sayısında önemli artış olmuştur. Türkiye'deki GYO'ların yıllara göre sayısal dağılımı aşağıda Tablo 1'de gösterilmiştir.

Tablo 1. GYO’ların Yıllara Göre Sayısal Dağılımı

\begin{tabular}{|c|c|c|c|}
\hline Yil & GYO Sayısı & Yil & GYO Sayıs1 \\
\hline 1997 & 2 & 2008 & 14 \\
\hline 1998 & 5 & 2009 & 14 \\
\hline 1999 & 8 & 2010 & 21 \\
\hline 2000 & 8 & 2011 & 23 \\
\hline 2001 & 8 & 2012 & 25 \\
\hline 2002 & 9 & 2013 & 30 \\
\hline 2003 & 9 & 2014 & 31 \\
\hline 2004 & 9 & 2015 & 31 \\
\hline 2005 & 9 & 2016 & 31 \\
\hline 2006 & 11 & 2017 & 31 \\
\hline 2007 & 13 & 2018 & 33 \\
\hline
\end{tabular}

(http://www.spk.gov.tr/SiteApps/Yayin/AylikIstatistikBultenleri, Erișim: 08.07.2019).

Türkiye' deki GYO'ların net aktif değerleri toplamı 1997 yılında 8.800.000 TL iken 2018 yılında ise 79.414.634.000 TL'ye yükselmiştir. Yıllara göre GYO'ların net aktif değer dağılımı aşağıda Tablo 2' de gösterilmiştir.

Tablo 2. GYO'ların Yıllara Göre Net Aktif Değer Dağılımı

\begin{tabular}{lccc}
\hline Y11 & Net Aktif Değer (000 TL) & Yll & Net Aktif Değer (000 TL) \\
\hline 1997 & 8.800 & 2008 & 4.269 .388 \\
\hline 1998 & 135.799 & 2009 & 4.346 .030 \\
\hline 1999 & 418.513 & 2010 & 13.907 .411 \\
\hline 2000 & 531.873 & 2011 & 20.769 .996 \\
\hline 2001 & 890.575 & 2012 & 24.086 .877 \\
\hline 2002 & 1.081 .125 & 2013 & 37.572 .732 \\
\hline
\end{tabular}




\begin{tabular}{llll}
\hline 2003 & 1.178 .915 & 2014 & 42.653 .446 \\
\hline 2004 & 1.382 .911 & 2015 & 52.530 .355 \\
\hline 2005 & 2.209 .379 & 2016 & 60.602 .223 \\
\hline 2006 & 2.480 .857 & 2017 & 67.161 .605 \\
\hline 2007 & 3.886 .043 & 2018 & 79.414 .634 \\
\hline Kaynak: & SPK & Aylik & İ̈̈tatistiki
\end{tabular}

(http://www.spk.gov.tr/SiteApps/Yayin/AylikIstatistikBultenleri, Erișim: 08.07.2019).

Türkiye' deki GYO'ların piyasa değerleri toplamı 1997 yılında 15.000.000 TL iken 2018 yılında 19.362.622.000 TL'ye yükselmiştir. Yıllara göre GYO'ların piyasa değeri dağılımı aşağıda Tablo 3'de gösterilmiştir.

Tablo 3. GYO’ların Yıllara Göre Piyasa Değeri Dağılımı

\begin{tabular}{lclc}
\hline Yll & Piyasa Değeri (000 TL) & Yll & Piyasa Değeri (000 TL) \\
\hline 1997 & 15.000 & 2008 & 3.045 .946 \\
\hline 1998 & 37.519 & 2009 & 2.853 .765 \\
\hline 1999 & 421.028 & 2010 & 11.062 .318 \\
\hline 2000 & 313.307 & 2011 & 11.708 .492 \\
\hline 2001 & 475.975 & 2012 & 15.781 .822 \\
\hline 2002 & 338.714 & 2013 & 18.632 .452 \\
\hline 2003 & 543.092 & 2014 & 21.981 .323 \\
\hline 2004 & 1.445 .753 & 2015 & 21.279 .729 \\
\hline 2005 & 2.489 .225 & 2016 & 24.961 .535 \\
\hline 2006 & 2.081 .671 & 2017 & 26.924 .062 \\
\hline 2007 & 3.189 .974 & 2018 & 19.362 .622 \\
\hline Kaynak: & SPK & $2019)$ & Ayllk
\end{tabular}

(http://www.spk.gov.tr/SiteApps/Yayin/AylikIstatistikBultenleri, Erișim: 08.07.2019).

Türkiye'deki gayrimenkul sektörünün gelişmesine bağlı olarak nitelikli konut, işyeri, alışveriş merkezleri, hastane gibi projelerin gerçekleştirilmesinde GYO'lar önemli bir sermaye piyasası oyuncusu olarak öne çıkmaktadır. GYO sektöründe GYO'ların karlarını artırma, maliyetlerini düşürme ve piyasa paylarını büyütme hedeflerini gerçekleştirebilmeleri için piyasa yapısının serbest piyasa koşullarına uygun olması beklenir. Bu nedenle düzenleyici otorite ve politika yapıcısı, piyasadaki aksaklığı tespit etme ve rekabeti geliştirme için piyasa yapısı ve yoğunlaşma düzeylerini ölçebilir. Bu amaçla çeşitli ölçüm teknikleri kullanılabilir. Yapı-Davranış-Performans yaklaşımı kapsamında N-Yoğunlaşma Oranı (CRN) ve HerfindahlHirschman (HHI) Endeksi, en çok tercih edilen tekniklerdir. Literatürde bu tekniklerin yanında Rosenbluth Endeksi (RI), Entropi Endeksi (EI) ve Kapsamlı Yoğunlaşma Endeksi (CCI) gibi teknikler de kullanılmaktadır. Yoğunlaşma endeksleri, piyasa yapısının belirlenmesinde pratik ve yararlı bilgiler sağlayarak piyasanın rekabet düzeyi hakkında ipuçları verir. Piyasada faaliyet gösteren firma sayısının fazla olması, firmaların piyasa paylarının birbirine yakın olduğunu gösterir. Firma sayısının fazlalığı, yoğunlaşma oranının azalmasını ve rekabetin artmasını sağlar. Piyasadaki rekabetin yüksekliği, firmaların piyasayı etkileme gücünü düşürür (Ediz \& Önder, 2019; Durukan \& Hamurcu, 2009). Bu çerçevede sayıları gittikçe artan Türkiye'deki GYO'ların piyasa yapısı ve yoğunlaşma düzeylerinin ölçülmesi önem arz etmektedir. 
Çalışmada Borsa İstanbul'da hisse senetleri işlem gören GYO'ların piyasa yapısı ve yoğunlaşma düzeylerinin belirlenmesi için 2007-2018 dönem verisi analiz edilmiştir. Ampirik analizler için $\mathrm{CR}_{\mathrm{N}}$ ve $\mathrm{HHI}$ endeksleri kullanılmıştır. Çalışmada ilk olarak literatür incelemesi, sonraki bölümde veri ve yöntem açıklanmıştır. Bundan sonra ise uygulama ile tartışma ve sonuç bölümüne yer verilmiştir.

\section{Literatür İncelemesi}

Literatür incelemesinde öncelikle GYO'lar üzerine yapılan çalışmalar özetlenecektir. Daha sonra piyasa yapısı ve yoğunlaşma düzeylerini ölçen yöntemlerin kullanıldığı, çeşitli sektör uygulamaları özetlenecektir.

\section{GYO'lar Üzerine Yapılan Çalışmalar}

GYO'lar üzerine yapılan çalışmalarda daha çok performans veya etkinlik analizinin yapıldığı, ayrıca değişkenler arasındaki ilişkilerin regresyon yöntemiyle analiz edildiği görülmüştür. Bu çerçevede GYO'lar üzerine yapılan çalışmalardan bazıları Tablo 4'de özetlenmiştir.

Tablo 4. GYO'lar Üzerine Yapılan Çalışmalar

\begin{tabular}{|c|c|c|}
\hline Yazar (lar) / Y1l & Yöntem & Uygulama \\
\hline Yilmaz-Türkmen (2011) & VZA & Finansal etkinlik analizi \\
\hline Şahin (2014) & Çoklu Regresyon Analizi & $\begin{array}{l}\text { GYO endeksi ile firmaya özgü değişkenler } \\
\text { arasındaki ilişkinin analizi }\end{array}$ \\
\hline $\begin{array}{l}\text { Aytekin \& Kahraman } \\
(2015)\end{array}$ & VZA & $\begin{array}{l}\text { VZA- Süper Aylak Tabanlı Model ile } \\
\text { performans değerlemesi }\end{array}$ \\
\hline İslamoğlu vd. (2015) & TOPSIS & $\begin{array}{llll}\begin{array}{l}\text { Entropi Temelli TOPSIS ile performans } \\
\text { değerlemesi }\end{array} & & \\
\end{array}$ \\
\hline Zügül \& Şahin (2015) & Çoklu Regresyon Analizi & $\begin{array}{l}\text { GYO endeks getirisi, kısa vadeli mevduat faiz } \\
\text { oranı ve enflasyon oranı arasındaki ilişkinin } \\
\text { analizi }\end{array}$ \\
\hline Erdogan vd. (2016) & FAHP, TOPSIS, VIKOR & Performans değerlemesi \\
\hline Karakaya (2017) & VZA & $\begin{array}{l}\text { Etkinlikler ve hisse senedi değeri arasındaki } \\
\text { ilişkinin belirlenmesi }\end{array}$ \\
\hline Çelik \& Manan (2018) & $\begin{array}{l}\text { Yatay Kesit Çoklu } \\
\text { Regresyon }\end{array}$ & Risk ve performans arasındaki ilişkinin analizi \\
\hline Gümüş \& Çıbık (2018) & DUPONT & Performansın ölçülmesi \\
\hline Kandır \& Özhan (2018) & Regresyon Analizi & Pay getirilerini etkileyen faktörlerin analizi \\
\hline Münyas (2018) & VZA & Finansal etkinlik analizi \\
\hline Yetgin \& İçten (2018) & TOPSIS & Performans değerlemesi \\
\hline Yilmaz \& İçten (2018) & TOPSIS & Nakit akım odaklı finansal performans analizi \\
\hline Yilmaz (2019) & TOPSIS & Performans değerlemesi \\
\hline
\end{tabular}

\section{Piyasa Yapısı ve Yoğunlaşma Düzeyinin Belirlenmesi Üzerine Yapılan Çalışmalar}

Firmaların piyasa yapısı ve yoğunlaşma düzeylerinin belirlenmesi üzerine farklı sektör uygulamalarını içeren çalışmalar literatürde yer almaktadır. Bu çerçevede Un Sektörü (Aktaş \& Yurdakul, 2001), İmalat Sanayi (Akan, 2002), Elektrik Piyasası (Matthes vd., 2005), Çimento Sektörü (Polat, 2007), Bankacılık Sektörü (Yayla, 2007), Otomotiv Sektörü (Kaynak \& Ari, 
2011), Demir Çelik Sektörü (Pehlivanoğlu \& Yavuz-Tiftikçigil, 2013), İnşaat Sektörü (PulajBrakaj \& Kume, 2013), Sivil Havacılık Sektörü (Sarıbaş \& Tekiner, 2015), Tarım İlaçları Sektörü (Özbek \& Fidan, 2016), Mobil İletişim Sektörü (Demirci, 2016), Türk İlaç Sektörü (Kaynak, 2016), Beyaz Eşya Sektörü (Tatlı, 2018) üzerine yapılmış çalışmalar örnek olarak gösterilebilir. Literatür incelemesinde GYO'ların piyasa yapısı ve yoğunlaşma düzeylerini inceleyen Burucu \& Yıldız-Contuk (2016) ile Dabara vd. (2018) tarafından yapılan sınırlı sayıda çalışmaya rastlanılmıştır. Literatürde piyasa yapısı ve yoğunlaşma düzeyleri üzerine sektörel bazda yapılan çalışmalar aşağıda kronolojik olarak özetlenmiş ve ulaşılan bulgular sunulmuştur.

Gıda Sektörü kapsamında Türkiye' deki Un Sektörü ile Bisküvi, Çikolatalı ve Şekerli Mamuller Sektörü ile Çiğ Süt Sektörü'nün piyasa yapısı ve yoğunlaşma düzeyleri incelenmiştir. Bu kapsamda Aktaş \& Yurdakul (2001) tarafından Türkiye'deki Un Sektörü'nün piyasa yapısı ve yoğunlaşma düzeyi incelenmiştir. Çalışmada Akdeniz Bölgesi (Adana ilinden 7), İç Anadolu Bölgesi (Ankara ilinden 4 ve Konya ilinden 10), Batı Anadolu Bölgesi (Balıkesir ilinden 6), Trakya Bölgesi (Tekirdağ ilinden 5), Doğu ve Güneydoğu Anadolu Bölgesi (Gaziantep ilinden 11), Karadeniz Bölgesi (Samsun ilinden 6)'nden toplam 49 işletmenin 1985-1997 dönem verisi analiz edilmiştir. Analizler için N-Firma Yoğunlaşma Oranı $\left(\mathrm{CR}_{4}\right.$ ve $\left.\mathrm{CR}_{8}\right)$ ve $\mathrm{HHI}$ endeksi kullanılmıştır. Ampirik analiz sonucunda Türkiye'deki Un Sanayi Sektörü'ndeki yoğunlaşma oranında genel bir artış olduğu, ancak yoğunlaşmanın çok düşük bir seviyede olduğu belirlenmiştir. Önder (2016) tarafından Türk Bisküvi, Çikolatalı ve Şekerli Mamuller Sektörü'nün 1997-2014 dönem verisi; N-Firma Yoğunlaşma Oranı (CR 4 , CR8), HHI, Entropi ve Rosenbluth endeksleri ile analiz edilmiştir. Çalışma ile $C_{4}$ ve $C R 8$ yoğunlaşma oranlarına göre piyasanın oligopolist bir yapıda olduğu, ancak dönem sonlarına doğru tekelci rekabet piyasasının oluştuğu gözlenmiştir. HHI endeksine göre ise oligopolistik piyasa yapısının olduğu tespit edilmiştir. Günlü (2011) tarafından 2008 yılında Burdur ilinden çiğ süt temin eden 19 adet süt sanayi işletmesinin yoğunlaşma düzeyleri; N-Firma Yoğunlaşma Oranı (CR4 ve $C_{8}$ ), CCR, $H H I$ ve Entropi endeksleri ile tespit edilmiştir. Ampirik analizlerde Burdur ili çiğ süt pazarında yoğunlaşma oranının yüksek olduğu ve piyasanın oligopson özelliklerine yakın olduğu tespit edilmiştir.

Türk İmalat Sanayi'nin 1980-1996 dönemi yoğunlaşma eğilimleri, Akan (2002) tarafından belirlenmek hedeflenmiştir. Bu amaçla 86 imalat alt-sektörünün analizi için yoğunlaşma oranı $\left(\mathrm{CR}_{4}\right)$ kullanılmıştır. Ampirik analizlerde imalat sanayinin yoğunlaşma oranının yüksek olduğu, yoğunlaşmada dönemler itibariyle farklılıklar olmasına rağmen yoğunlaşma aralığ ve piyasa yapısının önemli ölçüde değişim göstermediği tespit edilmiştir. Pehlivanoğlu \& Yavuz-Tiftikçigil (2013) tarafından Demir-Çelik ve Metal Sanayi'nde faaliyet gösteren firmaların 1995-2001 dönem veri seti için $\mathrm{N}$-firma yoğunlaşma oranı $\left(\mathrm{CR}_{4}, \mathrm{CR}_{8}\right.$ ve $\left.\mathrm{CR}_{12}\right)$ ve $\mathrm{HHI}$ endeks değerleri hesaplanmıştır. Çalışmada HHI endeks değerine göre yoğunlaşma tespit edilemediği, $\mathrm{CR}_{4}{ }^{\prime}$ e göre piyasanın monopolcü rekabet olduğu, $\mathrm{CR}_{8}$ ve $\mathrm{CR}_{12}$ oranlarına göre piyasanın bazı yıllar dışında oligopolistik yapıya dönüştüğü gözlenmiştir. Kaynak (2016a) tarafından Giyim Eşyaları İmalatı Sektörü'nde yoğunlaşma ve piyasa yapısı, N-Firma Yoğunlaşma Oranı $\left(\mathrm{CR}_{4}, \mathrm{CR}_{8}\right)$ ve HHI endeksi ile analiz edilmiştir. Çalışma verisi, 1995-2014 yıllarını kapsamaktadır. CR4'e göre, yoğunlaşma kimi dönemlerde düşük kimi dönemlerde yüksek bulunmuştur. CRs'e göre, yoğunlaşma oranı 2002 ve 2003 yılları dışında hep yüksek çıkmıştır. HHI endeksine göre, sektörde 2008 yılına kadar düşük yoğunlaşma olduğu, 2008 yılından sonra ise orta düzeyde bir yoğunlaşma olduğu bulgusuna ulaşılmıştır. 
Türkiye'nin 1980-2005 dönemi dış ticaretteki ürün ve ülke bazlı yoğunlaşmasının ithalat ve ihracat üzerindeki etkisi, Kösekahyaoğlu (2007) tarafından belirlenmek amaçlanmıştır. Çalışmada veri setinin analizi için Gini-Hirschman (GH) yoğunlaşma endeksi kullanılmıştır. Çalışma ile Türkiye'nin dış ticaretindeki ürün ve ülke yoğunlaşma düzeyleri açısından olumlu sonuçlar elde edildiği belirlenmiştir.

Türk Çimento Sektörü'nün 2001-2005 dönem verisi, N-Firma Yoğunlaşma Oranı (CR4 ve CR8) ve HHI endeksi ile Polat (2007) tarafından analiz edilmiştir. Çalışmada Türk Çimento Sektörü'nün CR yoğunlaşma oranına göre monopolcü rekabet ile oligopol piyasası arasında olduğu, HHI endeksine göre ise daha rekabetçi bir piyasa yapısının hakim olduğu tespit edilmiştir.

Bankacılık Sektörü'nün piyasa yapısı ve yoğunlaşma düzeyini inceleyen çalışmalar literatürde yer almaktadır. Bunlardan Yayla (2007) tarafından Türk Bankacılık Sektörü'nün 1995-2005 dönemi yoğunlaşma düzeyleri; CR7, HHI, Entropi, Kapsamlı Yoğunlaşma Endeksi (CCI), Rosenbluth-Hall-Tideman Endeksi (RHTI) ve Hannah-Kay Endeksi (HKI) ile belirlenmiştir. Çalışma ile Türk Bankacılık Sektörü'ndeki piyasa yoğunlaşmasının 1995-1999 döneminde azalma eğilimi, buna karşın 2000-2005 döneminde ise artış eğilimi gösterdiği belirlenmiştir. Hazar vd. (2017) tarafından 2001 krizi öncesi ve sonrası için Türk Bankacılık Sektörü'ndeki yoğunlaşma düzeyi; N-Firma Yoğunlaşma Oranı ( $\left.\mathrm{CR}_{5}, \mathrm{CR}_{7}, \mathrm{CR}_{10}\right), \mathrm{HHI}, \mathrm{HTI}$, RI, HKI, HM ve Entropi endeksleri ile belirlenmesi amaçlanmıştır. Bu amaçla iki ayrı dönemi (1988-2000 dönemi ve 2004-2015 dönemi) kapsayan veri seti analiz edilmiştir. Çalışmada 2001 krizi sonrasında sektörde yoğunlaşmanın yükseldiği gözlenmiştir. Koc vd. (2017) tarafından 20042014 yıllarında Türk Bankacılık Sektörü'nün piyasa yapısı; N-Firma Yoğunlaşma Oranı (CR2, $\mathrm{CR}_{3}, \mathrm{CR}_{4}, \mathrm{CR}_{10}$ ) ve $\mathrm{HHI}$ endeksine göre araştırılmıştır. Çalışmada Türk Bankacılık Sektörü'nün monopolcü rekabet piyasa yapısında olduğu tespit edilmiştir.

Türk Otomotiv Sanayi'nde hafif binek ve ticari araç alt sektörlerinin 2003-2010 dönem verisi, Kaynak \& Arı ( 2011) tarafından N-Firma Yoğunlaşma Oranı (CR4 ve CR8) ve HHI endeksi ile analiz edilmiştir. Çalışmada $\mathrm{CR}_{4}$ 'e göre yerli binek ve yerli hafif ticari, $\mathrm{CR}_{\text {s' }} \mathrm{e}$ göre ise yerli hafif ticari ve ithal hafif ticari araç sektöründe yoğunlaşmanın yüksek olduğu görülmüştür. Diğer yandan $\mathrm{HHI}^{\prime}$ ya göre yerli hafif ticari ve yerli binek araç sektöründe monopolcü rekabet piyasa yapısının olduğu, ithal binek ve ithal hafif ticari araç sektöründe ise düşük yoğunlaşmanın olduğu görülmüştür. Ildırar \& Kıral (2018) tarafından Türk Otomotiv Sektörü'ndeki piyasa yapısı ve yoğunlaşma düzeyi; N-Firma Yoğunlaşma $\left(\mathrm{CR}_{4}, \mathrm{CR}_{8}\right)$ ve $\mathrm{HHI}$ endeksi ile belirlenmesi hedeflenmiştir. Çalışmada 2004-2017 dönem verisi analiz edilmiştir. Türk Otomotiv Sektörü'nde CR4 ve CRs'e göre yerli binek otomobil ve hafif ticari araç piyasasında yoğunlaşmanın oldukça yüksek olduğu tespit edilmiştir. HHI endeksine göre sektörün tekelci rekabete yakın olduğu, buna karşın ithal binek ve ithal hafif ticari araç sektörünün daha rekabetçi yapıda olduğu gözlenmiştir.

İletişim sektörünün piyasa yapısı ve yoğunlaşma düzeyleri kapsamında Yıldız (2012) tarafından Türkiye'deki Mobil İletişim ve İnternet Servis Sağlayıcıları Sektörü'nün piyasa yoğunlaşması; 2000-2011 dönem verisi ve HHI endeksi ile belirlenmesi hedeflenmiştir. Çalışma ile sektörde oligopol bir piyasa yapısının olduğu, ancak piyasadaki yoğunlaşma düzeyinin gittikçe azalma ile rekabette bir artma olduğu sonucuna ulaşılmıştır. Kostakoğlu (2015) tarafından Türkiye'deki İnternet Servis Sağlayıcı Sektörü'ndeki firmaların yoğunlaşma düzeyleri N-Firma Yoğunlaşma Oranı $\left(\mathrm{CR}_{4}, \mathrm{CR} 8\right)$, HHI ve Entropi endeksleri ile belirlenmesi hedeflenmiştir. Çalışmada firmaların 2011-2014 dönem verisi analiz edilmiştir. Analizlerde 
Türkiye'deki İnternet Servis Sağlayıcıları Sektörü'nde yüksek düzeyde yoğunlaşmanın olduğu tespit edilmiştir. Demirci (2016) tarafından Türkiye'de Mobil İletişim Sektörü'nün piyasa yapısı tespit edilmeye çalışılmıştır. Çalışmada 2005-2014 dönem verisi ve HHI endeksi kullanılmıştır. HHI endeks değerlerine göre piyasa yapısının rekabetçi olmadığı ve aşırı yoğunlaşmış oligopol bir piyasa olduğu sonucuna ulaşılmıştır. Krstic vd. (2016) tarafından Sırbistan'daki Mobil İletişim Sektörü'nün piyasa yapısı ve yoğunlaşma düzeyi; $C_{2}$, HHI, Entropi, Göreceli Entropi, HTI, Rosenbluth, HKI, CCI ve Gini endeksleri ile belirlenmesi amaçlanmıştır. Çalışmada 2009-2014 dönem verisi analiz edilmiştir. Çalışma ile Sırbistan'daki Mobil İletişim Sektörü için çeşitli endekslere göre belirlenen yoğunlaşmanın oldukça yüksek olduğu ve yoğunlaşma düzeyinin Avrupa Birliği'ne üye ülkelerinin ortalamasının üzerinde olduğu tespit edilmiştir. Durukan \& Hamurcu (2009) çalışmalarında Türkiye, Kazakistan, Kırgızistan, Türkmenistan, Tacikistan ve Özbekistan'daki Mobil İletişim Sektörü'nün piyasa yapısı ve yoğunlaşma düzeyini; 2002-2007 dönem verisi ile HHI endeksine göre analiz etmiştir. Çalışma ile Türkiye, Kazakistan, Kırgızistan ve Türkmenistan ülkelerinde rekabetçi olmayan oligopol piyasa yapısının olduğu, Tacikistan ve Özbekistan ülkelerinde ise orta derecede yoğunluğa sahip oligopol bir piyasa yapısının bulunduğu tespit edilmiştir.

Enerji Sektörü'nün piyasa yapısı ve yoğunlaşma düzeyleri üzerine yapılan çalışmalar kapsamında Pehlivanoğlu \& Tekçe (2013) Türkiye'deki Elektrik Enerjisi Piyasası'nın yoğunlaşma düzeyini; 1993-2011 dönem verisi, N-Firma Yoğunlaşma Oranı (CR4 ve CR8) ve HHI endeksi ile belirlemeye çalışmıştır. Analiz sonuçlarında Türkiye'de Elektrik Enerjisi Piyasası'nın $\mathrm{CR}_{4}$ ve $\mathrm{HHI}$ ye göre piyasa yoğunlaşmasının yüksek olduğu görülmüştür. Bu nedenle piyasanın rekabetçi yapıdan uzak olduğu sonucuna ulaşılmıştır. Matthes vd. (2005) tarafından Avrupa ülkelerindeki Elektrik Enerjisi Sektörü'nün piyasa yoğunlaşma düzeyinin belirlenmesi hedeflenmiştir. Bu amaçla analizlerde N-Firma Yoğunlaşma Oranı $\left(\mathrm{CR}_{1}, \mathrm{CR}_{3}\right.$, $\mathrm{CR}_{5}$ ) ve HHI endeksleri kullanılmıştır. Araştırma verisi, 1996-2004 dönemini kapsamaktadır. Çalışmada Avrupa ülkelerinin Elektrik Enerjisi Sektörü'ndeki yoğunlaşma düzeyinin azalma gösterdiği gözlenmiştir.

İnşaat sektörünün piyasa yapısı ve yoğunlaşma düzeyinin belirlenmesi üzerine Pulaj-Brakaj \& Kume (2013) tarafından Arnavutluk'un Vlora Bölgesi'ndeki İnşaat Sektörü analiz edilmiştir. Analizlerde N-Firma Yoğunlaşma Oranı (CR4), HHI ve Gini endeksleri ile 2003-2012 dönem veri seti kullanılmıştır. Ampirik analizlerde Arnavutluk'un Vlora Bölgesi'ndeki İnşaat Sektörü'nde yoğunlaşmanın bulunmadığı tespit edilmiştir.

Ulaşım Sektörü'nün piyasa yapısı ve yoğunlaşma düzeylerini inceleyen çalışmalar arasında Sarıbaş \& Tekiner (2015) tarafından Türk Sivil Havacılık Sektörü'nün 2011-2013 dönemi için piyasa yapısı ve yoğunlaşma düzeyi; N-Firma yoğunlaşma oranı $\left(\mathrm{CR}_{2}, \mathrm{CR}_{4}\right)$ ve $\mathrm{HHI}$ endeks ile analiz edilmiştir. Araştırmada Türk Sivil Havacılık Sektörü'nde yoğunlaşmanın yüksek olduğu, rekabet düzeyinin ise oligopol piyasasına yakın olduğu tespit edilmiştir. Yaşar vd. (2017) tarafından Türk Havacılık Sektörü'nde yoğunlaşma ve piyasa yapısı; N-Firma Yoğunlaşma Oranı $\left(\mathrm{CR}_{4}\right)$ ve HHI Endeksi ile 2012-2015 dönem verisi analiz edilmiştir. Çalışmada havacılık piyasasının rekabetçi yapıdan uzak olduğu tespit edilmiştir. Yaşar \& Kiracı (2018) tarafından Dünya Havayolu Sektörü'nün 2006-2015 dönem verisi; N-Firma Yoğunlaşma Oranı $\left(\mathrm{CR}_{4}, \mathrm{CR} 8\right)$, HHI, CCI ve Entropi endekslerine göre analiz edilmiştir. Çalışmada piyasanın genel olarak rekabetçi olduğu, ayrıca piyasa yapısında önemli değişimlerin olduğu tespit edilmiştir. 
GYO sektörünün piyasa yapısı ve yoğunlaşma düzeylerinin belirlenmesi kapsamında Burucu \& Yıldız-Contuk (2016) tarafından 2000-2014 dönem verisi ile Türk GYO Sektörü'nün piyasa yapısı; yoğunlaşma oranı $\left(\mathrm{CR}_{4}, \mathrm{CR}_{5}\right)$ ve $\mathrm{HHI}$ endeksi ile analiz edilmiştir. Ampirik analizlerde Türkiye'deki GYO Sektörü'nün genel olarak oligopol piyasa yapısında olmasına rağmen son yıllarda monopolcü rekabet yapısına dönüştüğü tespit edilmiştir. Dabara vd. (2018) tarafından Nijerya'daki GYO sektörü için 2008-2016 dönem verisi kullanılarak N-Yoğunlaşma Oranı $\left(\mathrm{CR}_{4}\right)$ ve HHI endeksleri hesaplanmıştır. Çalışma ile Nijerya'da GYO Sektörü'nün yüksek yoğunlaşmaya sahip olduğu ve oligopol bir piyasa yapısının bulunduğu belirlenmiştir.

İlaç sektörünün piyasa yapısı ve yoğunlaşma düzeylerinin belirlenmesi kapsamında Kaynak (2016b) tarafından Türk İlaç Sektörü, N-Ffirma Yoğunlaşma Oranı (CR4, CR8) ve HHI endeksi ile analiz edilmiştir. Analizler için 2005-2015 dönem verisi kullanılmıştır. Çalışmada $\mathrm{CR}_{4}$ ve CRs'e göre yoğunlaşma oranın düşük olduğu ve oligopol bir piyasa yapısının olduğu gözlenmiştir. HHI indeksine göre yoğunlaşma oranının yüksek olmadığı tespit edilmiştir. Ipek \& Ipek (2018) tarafından Türk İlaç Sektörü; N-Firma Yoğunlaşma Oranı (CR 3 , CR4), HHI, Entropi, RHTI, CCI, H-K İndeksi, Hause ve Gini endeksleri ile analiz edilmiştir. Analizler için 2009-2016 dönem verisi kullanılmıştır. Çalışma ile Türk İlaç Sektörü'nün düşük yoğunluklu bir piyasa yapısına sahip olduğu tespit edilmiştir. Ayrıca Özbek \& Fidan (2016) çalışmalarında Konya ilinde Tarım İlaçları Sektörü'nü, N-Firma Yoğunlaşma Oranı (CR4, CR8) ve HHI endeksi ile analiz etmiştir. Çalışmada Tarım İlaçları Sektörü'nde oligopol bir piyasa yapısının olduğu gözlenmiştir.

Türkiye Beyaz Eşya Sektörü'ndeki yoğunlaşma düzeyi; Tatlı (2018) tarafından yapılan çalışmada 2005-2015 yılları verisi ile analiz edilmiştir. Çalışmada N-Firma Yoğunlaşma Oranı $\left(\mathrm{CR}_{3}, \mathrm{CR}_{4}\right)$, HHI, Entropi, RHTI, H-K İndeksi ve Gini Endeksleri kullanılmıştır. Çalışma ile sektörde yoğunlaşma düzeyinin yüksek olduğu ve piyasanın oligopol özelliğe yakın olduğu tespit edilmiştir.

\section{Veri ve Yöntem}

Türkiye' deki GYO sektöründe piyasa yapısı ve yoğunlaşma düzeylerini belirlemek amacıyla hisse senetleri Borsa İstanbul'da işlem gören GYO'ların 2007-2018 dönem verisi analiz edilmiştir. Ampirik analizler için veri seti, www.spk.gov.tr ve www.kap.org.tr adreslerinden sağlanmıştır.

Yoğunlaşmayı (C); sektörde faaliyet gösteren GYO sayısını (n) ve “GYO'nun aktif büyüklüğü eşitsizlik endeksi"ni temsilen (I)'nın oluşturduğu bir fonksiyon olarak düşünmek mümkündür. Bu fonksiyonda GYO sayısının artması ile sektördeki yoğunlaşma düzeyi azalmaktadır. Buna karşın fonksiyondaki eşitsizlik endeksinin artması ile yoğunlaşmanın artması beklenir. Bu durum matematiksel olarak (1) nolu eşitlikle ifade edilmektedir (Yayla, 2007:41-42).

$C=f(n, I) \quad f_{n}<O$ ve $f_{I}>0$

Sektörlerin piyasa yapısı ve yoğunlaşma düzeylerini belirlemede farklı endekslerin kullanıldığı literatür incelemesinde görülmüştür. Bu çalışmada literatürde en çok tercih edilen N-Firma Yoğunlaşma Oranı $\left(\mathrm{CR}_{\mathrm{N}}\right)$ ve Herfindahl-Hirschman Endeksi (HHI) kullanılmıştır. 


\section{N-Firma Yoğunlaşma Oranı (CRN)}

N-Firma Yoğunlaşma Oranı $(\mathrm{CRN})$, GYO sektöründeki $N$ tane en büyük GYO'nun aktif varlıkları toplamının sektörün aktif varlıklarının toplamı içindeki yüzde payını göstermektedir. Bu kapsamda (2) nolu formüldeki $X_{i}$; i. GYO'nun piyasa payını temsil etmektedir. $\mathrm{N}$ ise kaç tane GYO'nun sektördeki kontrol gücünü temsil etmektedir. $\mathrm{n}$ ise sektörde faaliyet gösteren GYO'ların sayısını temsil etmektedir. Dolayısıyla $\mathrm{N}$ arttıkça yoğunlaşma oranı, 100'e yaklaşmaktadır (Yayla, 2007:42; Ediz \& Önder, 2019:27; Yaşar \& Kirac1, 2018:734; Polat, 2007:100).

$C R_{N}=\frac{1}{x} \sum_{i=1}^{n} x_{i}$

Genellikle isteğe bağlı olarak seçilen GYO sayısı (N)'na göre hesaplanan bu oran, 0'dan büyük ve 100 'den küçüktür. Bu oranda N'nin neye göre belirlendiği üzerinde kesin bir kıstas bulunmamaktadır. Ancak yoğunlaşma oranı belirlenirken genelde ilk 4, veya 8 firma dikkate alınmaktadır. Firma sayısı için sektörün büyüklüğü, sektörün karakteristikleri gibi unsurlar dikkate alınmalıdır (Yayla, 2007:42; Ediz \& Önder, 2019:27; Yıldız, 2012:50 Akgün-Güngör, 2014:50; Pehlivanoğlu \& Tekçe, 2013:374).

Türkiye İstatistik Kurumu tarafından yapılan Yıllık Sanayi ve Hizmet İstatistikleri (YSHİ) araştırmasında kullanılan $\mathrm{CR}_{4}$ yoğunlaşma oranları; $\mathrm{CR}_{4}<30$ ise yoğunlaşma düşük ve rekabetçi piyasa, $30 \leq \mathrm{CR}_{4}<50$ ise yoğunlaşma orta ve monopolcü piyasa, $50 \leq \mathrm{CR}_{4}<70$ ise yoğunlaşma yüksek ve oligopolcü piyasa, $C_{4} \geq 70$ ise yoğunlaşma çok yüksek ve monopolcü piyasa yapısının olduğunu gösterir (TÜİK, 2015). Çalışmada GYO'ların yoğunlaşma oranlarının hesaplanmasında $\mathrm{CR}_{4}$ ve $\mathrm{CR}_{8}$ sınıflaması tercih edilmiştir. Piyasa yoğunlaşmasının değerlendirilmesinde $\mathrm{CR}_{4}$ için geçerli kriterler, $\mathrm{CR}_{8}$ yoğunlaşma oranı için de uygulanmıştır.

\section{Herfindahl-Hirschman Endeksi (HHI)}

Herfindahl-Hirschman Endeksi (HHI), GYO sektöründeki n tane GYO'nun piyasa paylarının (Pi) karelerinin toplamından oluşmaktadır. Şayet piyasada birden fazla GYO varsa her birinin piyasa payları, toplamda 100 olacak şekilde ifade edildiğinde HHI endeks değeri en fazla 10.000 değerini alır. Bu sonuç piyasada tek GYO'nun olduğu tekel durumunu ifade eder. Eğer birbirine eşit piyasa payına sahip çok sayıda GYO varsa HHI endeksi sıfıra yaklaşır (atomistik piyasa) ancak asla sıfıra eşit olmaz. GYO payları yüzde puan olarak hesaplanmadığında HHI endeks değer aralığı $(1 / n, 1)$ şeklinde olur (Yayla, 2007:42; Burucu \& Yıldız-Contuk, 2016:95).

$H H I=\sum_{i=1}^{n}\left(P_{i}\right)^{2}$

HHI Endeksi'nin $0<\mathrm{HHI}<1000$ arası değerde olması piyasa yoğunlaşmasının düşük olduğu (yüksek rekabet), 1000<HHI<1800 arası değerde olması piyasa yoğunlaşmasının orta olduğu (orta düzey rekabet), 1800<HHI<10000 arası değerde olması piyasa yoğunlaşmasının yüksek olduğu (düşük rekabet) şeklinde yorumlanır (Kaynak, 2016a:28; Burucu \& Yıldız-Contuk, 2016:95). 


\section{GYO’lar Üzerine Ampirik Bir Uygulama}

Türkiye'de GYO sektöründe faaliyet gösteren firmaların piyasa yapısı ve yoğunlaşma düzeyleri; yoğunlaşma oranı $\left(\mathrm{CR}_{4}, \mathrm{CR}_{8}\right)$ ve $\mathrm{HHI}$ endeksine göre hesaplanmıştır. $\mathrm{Bu}$ hesaplamalardan elde edilen değerler aşağıda karşılaştırmalı olarak gösterilmiştir.

Aktif büyüklük sıralamasına göre ilk dört GYO'nun birikimli payı için $\mathrm{CR}_{4}$ yoğunlaşma oranı değerleri Tablo 5'te gösterilmiştir.

Tablo 5. GYO'ların CR4 Yoğunlaşma Oranları (\%)

\begin{tabular}{lcccccc}
\hline GYO & $\mathbf{2 0 0 7}$ & $\mathbf{2 0 0 8}$ & $\mathbf{2 0 0 9}$ & $\mathbf{2 0 1 0}$ & $\mathbf{2 0 1 1}$ & $\mathbf{2 0 1 2}$ \\
\hline 1 & 29,33 & 27,90 & 28,77 & 41,70 & 36,18 & 34,85 \\
\hline 2 & 23,91 & 24,75 & 24,98 & 18,02 & 18,54 & 18,82 \\
\hline 3 & 22,62 & 21,94 & 20,94 & 10,09 & 9,69 & 8,36 \\
\hline 4 & 5,44 & 5,74 & 5,87 & 8,82 & 5,57 & 5,77 \\
\hline $\mathbf{C R}_{4}$ & $\mathbf{8 1 , 2 9}$ & $\mathbf{8 0 , 3 3}$ & $\mathbf{8 0 , 5 5}$ & $\mathbf{7 8 , 6 3}$ & $\mathbf{6 9 , 9 8}$ & $\mathbf{6 7 , 7 9}$ \\
\hline & & & & & & \\
\hline GYO & $\mathbf{2 0 1 3}$ & $\mathbf{2 0 1 4}$ & $\mathbf{2 0 1 5}$ & $\mathbf{2 0 1 6}$ & $\mathbf{2 0 1 7}$ & $\mathbf{2 0 1 8}$ \\
\hline 1 & 35,85 & 35,06 & 32,80 & 30,86 & 30,57 & 28,53 \\
\hline 2 & 16,86 & 16,46 & 16,83 & 17,09 & 16,88 & 15,46 \\
\hline 3 & 5,84 & 4,64 & 7,85 & 8,06 & 7,91 & 7,06 \\
\hline 4 & 4,44 & 4,36 & 3,90 & 4,02 & 6,35 & 6,58 \\
\hline $\mathbf{C R}_{4}$ & $\mathbf{6 2 , 9 9}$ & $\mathbf{6 0 , 5 2}$ & $\mathbf{6 1 , 3 8}$ & $\mathbf{6 0 , 0 3}$ & $\mathbf{6 1 , 7 0}$ & $\mathbf{5 7 , 6 2}$ \\
\hline
\end{tabular}

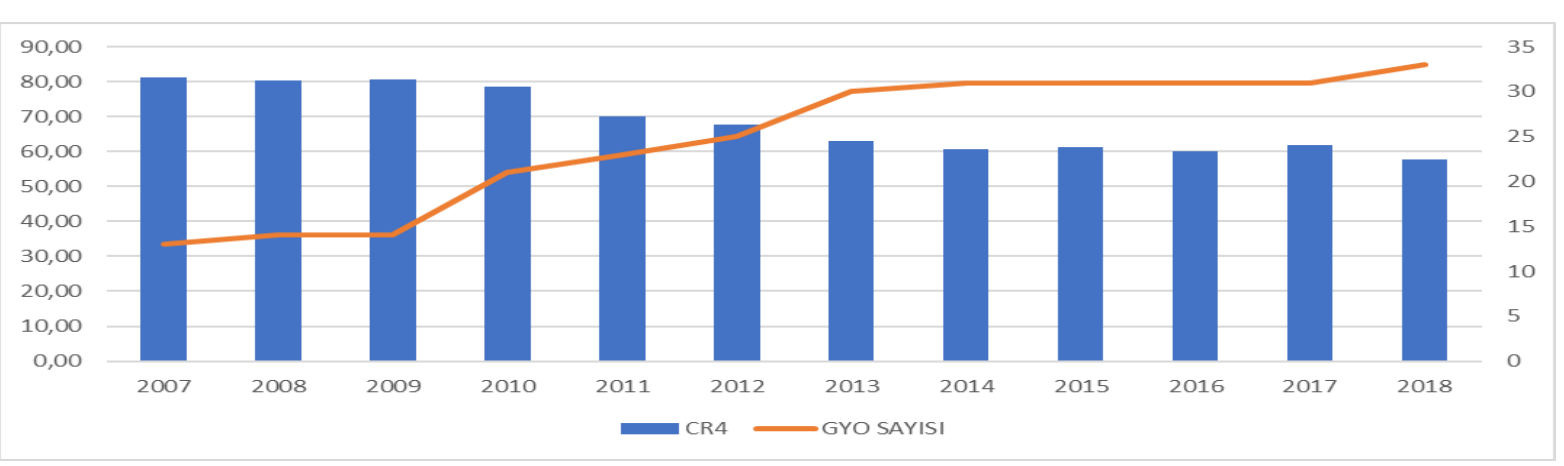

Grafik 1. GYO'ların CR4 Yoğunlaşma Oranları ve GYO Sayıları

Analiz sonuçlarına göre GYO sektöründe faaliyet gösteren en büyük dört GYO'nun yoğunlaşma oranları, \%57,62 ile \%81,29 arasında değerler almaktadır. Buna göre 2007, 2008, 2009 ve 2010 yıllarında yoğunlaşmanın \%70-\%80 aralığında olduğu Tablo 5 ve Grafik 1'de görülmektedir. Yoğunlaşmanın en yüksek değeri \%81,29 ile 2007 yılında, en düşük değeri ise \%57,62 ile 2018 y1lında gerçekleştiği tespit edilmiştir. 2011, 2012 ve 2013 yıllarında yoğunlaşmanın \%60-\%70 aralığında, ancak azalan bir eğilimde olduğu görülmüştür. 2014, 2015, 2016 ve 2017 yıllarında çok az bir farklılıkla yılların benzer yoğunlaşma değerleri aldığı ve yoğunlaşmanın ise yatay bir seyir gösterdiği belirlenmiştir. 2018 yılında ise önceki yıllara göre yoğunlaşmada oldukça azalma görülerek \%57,62 düzeyine indiği belirlenmiştir. 20072018 yıllarındaki yoğunlaşmanın değişimi üzerinde; 2007 yılında 13 olan GYO sayısının 2010 y1lında 21, 2013 yılında 30 ve 2018 yılında ise 33'e ulaşmasının etkisi ile piyasadaki yoğunlaşma düzeyinde azalma olmuştur. 2012 yılındaki yoğunlaşma oranı ile GYO sayısı 
arasındaki ayrışma, Grafik 1'de görülmektedir. 2012 yılında yoğunlaşma \%67,79 iken GYO sayısı 25, bu yıldan itibaren yoğunlaşma oranları önceki yıllara göre azalma göstermiştir. Ancak GYO sayısı, 2012 yılından itibaren artış göstermiştir. Sonuç olarak; CR4 yoğunlaşma oranı için 2007-2018 döneminde yoğunlaşma ile GYO sayısı arasında negatif bir korelasyon olduğu söylenebilir. CR 4 yoğunlaşma oranı içindeki GYO'ların payları incelendiğinde ise 2007, 2008 ve 2009 yıllarında birinci, ikinci ve üçüncü GYO'ların benzer ağırlık düzeylerini korudukları tespit edilmiştir. Ancak 2010 yılında birinci GYO'nun ağırlığı \%41,70 ile bütün dönemin en yüksek ağırlık düzeyi olarak gerçekleşmiştir. Buna karşın birinci sıradaki GYO'nun ağırlık düzeyi, 2010'dan 2018'e kadar sürekli bir azalma göstermiştir. Genel olarak GYO sektöründe yoğunlaşmanın yüksek ve rekabetin düşük olduğunu, $\mathrm{CR}_{4}$ değerleri göstermiştir. Ancak GYO sektöründe GYO sayısının artması ile beraber 2010 yılından itibaren yoğunlaşma oranlarında önemli düzeyde azalma olduğu Tablo 5 ve Grafik 1'de görülmektedir.

Aktif büyüklük sıralamasına göre ilk sekiz GYO'nun birikimli payı için CR8 yoğunlaşma değerleri Tablo 6'da gösterilmiştir.

Tablo 6. GYO'ların CR8 Yoğunlaşma Oranları (\%)

\begin{tabular}{lcccccc}
\hline GYO & $\mathbf{2 0 0 7}$ & $\mathbf{2 0 0 8}$ & $\mathbf{2 0 0 9}$ & $\mathbf{2 0 1 0}$ & $\mathbf{2 0 1 1}$ & $\mathbf{2 0 1 2}$ \\
\hline 1 & 29,33 & 27,90 & 28,77 & 41,70 & 36,18 & 34,85 \\
\hline 2 & 23,91 & 24,75 & 24,98 & 18,02 & 18,54 & 18,82 \\
\hline 3 & 22,62 & 21,94 & 20,94 & 10,09 & 9,69 & 8,36 \\
\hline 4 & 5,44 & 5,74 & 5,87 & 8,82 & 5,57 & 5,77 \\
\hline 5 & 4,95 & 4,15 & 4,36 & 5,72 & 5,15 & 4,88 \\
\hline 6 & 4,15 & 3,88 & 3,85 & 2,11 & 5,01 & 4,72 \\
\hline 7 & 3,51 & 3,19 & 2,32 & 1,90 & 4,56 & 3,40 \\
\hline 8 & 2,11 & 2,38 & 2,32 & 1,67 & 2,17 & 3,07 \\
\hline CR & $\mathbf{9 6 , 0 0}$ & $\mathbf{9 3 , 9 3}$ & $\mathbf{9 3 , 4 1}$ & $\mathbf{9 0 , 0 2}$ & $\mathbf{8 6 , 8 9}$ & $\mathbf{8 3 , 8 6}$ \\
\hline GYO & $\mathbf{2 0 1 3}$ & $\mathbf{2 0 1 4}$ & $\mathbf{2 0 1 5}$ & $\mathbf{2 0 1 6}$ & $\mathbf{2 0 1 7}$ & $\mathbf{2 0 1 8}$ \\
\hline 1 & 35,85 & 35,06 & 32,80 & 30,86 & 30,57 & 28,53 \\
\hline 2 & 16,86 & 16,46 & 16,83 & 17,09 & 16,88 & 15,46 \\
\hline 3 & 5,84 & 4,64 & 7,85 & 8,06 & 7,91 & 7,06 \\
\hline 4 & 4,44 & 4,36 & 3,90 & 4,02 & 6,35 & 6,58 \\
\hline 5 & 3,91 & 4,21 & 3,81 & 3,64 & 3,76 & 6,29 \\
\hline 6 & 3,40 & 3,61 & 3,40 & 3,30 & 3,54 & 4,60 \\
\hline 7 & 3,34 & 3,57 & 3,34 & 3,07 & 3,04 & 3,31 \\
\hline 8 & 2,97 & 3,17 & 3,25 & 3,07 & 2,97 & 2,85 \\
\hline CR & $\mathbf{7 6 , 6 0}$ & $\mathbf{7 5 , 0 8}$ & $\mathbf{7 5 , 1 8}$ & $\mathbf{7 3 , 1 1}$ & $\mathbf{7 5 , 0 1}$ & $\mathbf{7 4 , 6 8}$ \\
\hline
\end{tabular}

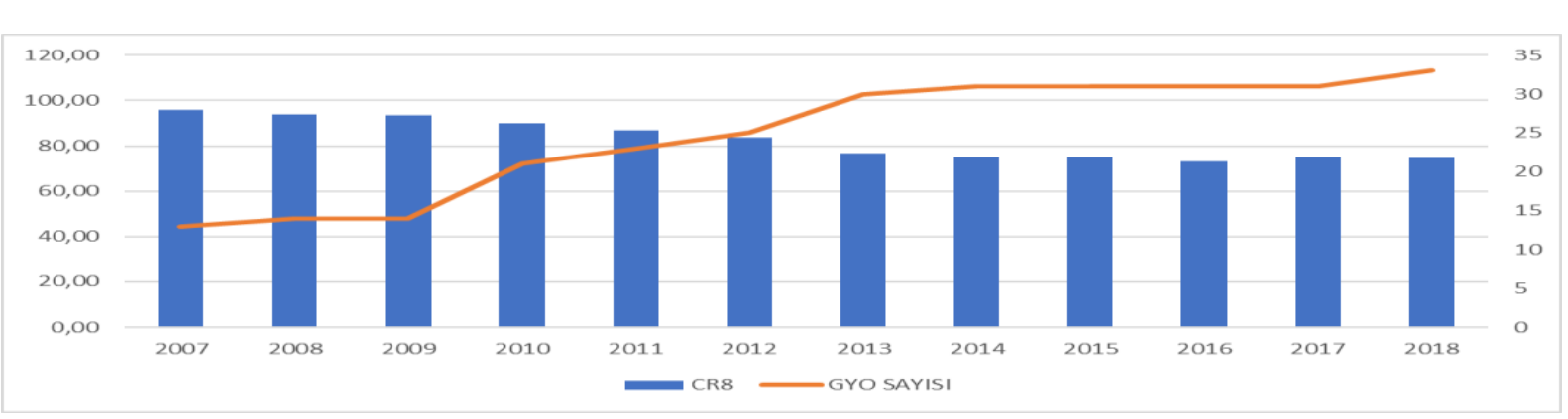

Grafik 2. GYO'ların CR8 Yoğunlaşma Oranları ve GYO Sayıları 
Analiz sonuçlarına göre GYO sektöründe faaliyet gösteren en büyük sekiz GYO'nun yoğunlaşma oranları, \%73,11 ile \%96,00 arasında yer almaktadır. Buna göre 2007, 2008, 2009, 2010, 2011 ve 2012 yıllarında yoğunlaşmanın \%70-\%80 aralığında olduğu Tablo 6 ve Grafik 2'de görülmektedir. 2013, 2014, 2015, 2016, 2017 ve 2018 yıllarında yoğunlaşmanın \%60-\%70 aralığında ve yaklaşık olarak benzer bir eğilimde olduğu görülmüştür. Yoğunlaşmanın en yüksek değeri \%96,00 ile 2007 yılında, en düşük değeri ise \%73,11 ile 2016 yılında gerçekleştiği tespit edilmiştir. Bu yıllardaki yoğunlaşmadaki değişim üzerinde; 2007 yılında 13 olan GYO sayısının 2010 yılında 21, 2013 yılında 30 ve 2018 yılında ise 33'e ulaşmasının etkisi ile piyasadaki yoğunlaşma düzeyinde azalma olmuştur. 2012 yılındaki yoğunlaşma oranı ile GYO sayısındaki ayrışma, Grafik 2'de görülmektedir. 2012 yılında yoğunlaşma \%83,86 iken GYO sayısı 25, bu yıldan itibaren yoğunlaşma oranları önceki yıllara göre düşüş göstermiştir. Ancak GYO sayısı, 2012 yılından itibaren artış göstermiştir. Sonuç olarak; CR8 yoğunlaşma oranı için 2007-2018 döneminde yoğunlaşma ile GYO sayısı arasında negatif bir korelasyon olduğu söylenebilir. CR8 yoğunlaşma oranı içindeki GYO'ların payları incelendiğinde 2007, 2008 ve 2009 yıllarında birinci, ikinci ve üçüncü GYO'ların benzer ağırlık düzeylerini korudukları tespit edilmiştir. Ancak 2010 yılında birinci GYO'nun ağırlığı \%41,70 ile bütün dönem için en yüksek ağırlık düzeyindedir. Buna karşın birinci sıradaki GYO'nun ağırlık düzeyi 2010'dan 2018'e kadar sürekli bir azalma göstermiştir. Üçüncü sıradaki GYO'nun payı, 2009 yılından itibaren \%10 düzeyinin altına düşmüştür. Bu düşüş 2014 yılında \%4,64 ile en düşük değer olarak gerçekleşmiştir. Genel olarak GYO sektöründe yoğunlaşmanın yüksek ve rekabetin düşük olduğu, CR8 değerleri ile Tablo 6' da gösterilmiştir. Ancak GYO sektöründeki GYO sayısının artması ile beraber 2010 yılından itibaren yoğunlaşma oranlarında önemli düzeyde azalma olduğu Tablo 6 ve Grafik 2'de görülmektedir.

Aktif büyüklük sıralamasına göre tüm GYO'ların paylarının kareleri toplamı olan HHI endeks değerleri, Tablo 7'de gösterilmiştir. Hesaplanan HHI endeks değerlerine göre GYO sektöründe faaliyet gösteren GYO'ların; 1272 ile en düşük HHI endeks değerinin 2018 yılında ve 2297 ile en yüksek HHI endeks değerinin ise 2010 yılında olduğu tespit edilmiştir. Buna göre 2007 ve 2010 yılındaki HHI endeks değerleri, 2000-2500 aralığında gerçekleşmiştir. 2008, 2009, 2011, 2012, 2013, 2014 ve 2015 yıllarındaki HHI endeks değerlerinin 1500-2000 aralığında gerçekleştiği tespit edilmiştir. 2016, 2017 ve 2018 yıllarında ise HHI endeks değerleri, 10001500 aralığında gerçekleşmiştir. Bu HHI endeks değerleri, ayrıntılı olarak Tablo 7 ve Grafik 3'de görülmektedir.

Tablo 7. GYO'ların HHI Endeks Değerleri

\begin{tabular}{lllllll}
\hline Y1l & $\mathbf{2 0 0 7}$ & $\mathbf{2 0 0 8}$ & $\mathbf{2 0 0 9}$ & $\mathbf{2 0 1 0}$ & $\mathbf{2 0 1 1}$ & $\mathbf{2 0 1 2}$ \\
\hline HHI Endeksi & 2036 & 1962 & 1979 & 2297 & 1869 & 1761 \\
\hline & & & & & & \\
\hline Y1l & $\mathbf{2 0 1 3}$ & $\mathbf{2 0 1 4}$ & $\mathbf{2 0 1 5}$ & $\mathbf{2 0 1 6}$ & $\mathbf{2 0 1 7}$ & $\mathbf{2 0 1 8}$ \\
\hline HHI Endeksi & 1711 & 1639 & 1527 & 1423 & 1415 & 1272 \\
\hline
\end{tabular}




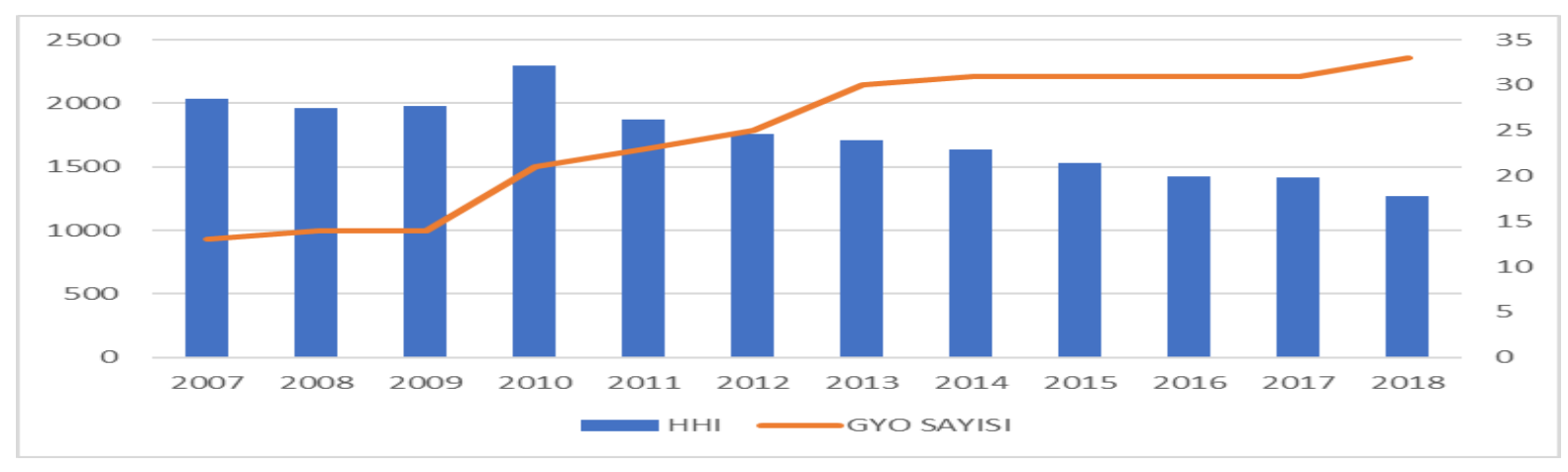

Grafik 3. GYO'ların HHI Endeks Değerleri ve GYO Sayıları

2007 yılında 13 olan GYO sayısının 2010 yılında 21'e ulaşması ile HHI endeks değerinin de en yüksek değere ulaştığ 1 tespit edilmiştir. 2010 yılından itibaren GYO sayısının artması ile HHI endeks değerleri arasındaki ayrışmanın 2012 yılında olduğu, Grafik 3'de görülmektedir. 2012 yılında HHI endeks değeri 1761 iken GYO sayısı 25'tir. 2012 yılından itibaren HHI endeks değerleri önceki yıllara göre genel bir azalma göstermiştir. Buna göre; 2007-2018 döneminde HHI endeks değerleri ile GYO sayıları arasında negatif bir korelasyon olduğu söylenebilir.

\section{Tartışma ve Sonuç}

Borsa İstanbul'da hisse senetleri işlem gören GYO'ların piyasa yapısı ve yoğunlaşma düzeylerini belirlemek için 2007-2018 dönem veri seti analiz edilmiştir. Bu amaçla GYO'ların yoğunlaşma oranı $\left(\mathrm{CR}_{4}, \mathrm{CR}_{8}\right)$ ve $\mathrm{HHI}$ endeks değerleri hesaplanmıştır.

Piyasa yapısı ve yoğunlaşma düzeylerinin belirlenmesinde farklı yöntemler kullanılmaktadır. Nijerya' daki GYO sektörü için Dabara vd. (2018) tarafından yoğunlaşma oranı (CR3) ve HHI endeksi kullanılmıştır. Benzer şekilde Türkiye' deki GYO sektörü için Burucu \& Yıldız-Contuk (2016) tarafından yapılan çalışmada yoğunlaşma oranı ( $C_{4}$ ve $\left.C_{5}\right)$ ve $H H I$ endeksi tercih edilmiştir. Bu çalışmada veri setinin analizi için diğer sektörlerde (Kostakoğlu, 2015; Ediz \& Önder, 2019; Polat, 2007; Kaynak, 2016a; Pehlivanoğlu \& Tekçe, 2013) sıklıkla kullanılan yoğunlaşma oranı $\left(\mathrm{CR}_{4}, \mathrm{CR}_{8}\right)$ ve $\mathrm{HHI}$ endeksi tercih edilerek ampirik analizler yapılmıştır.

Ampirik analizlerde CR4 yoğunlaşma oranına göre GYO sektöründe 2007-2010 döneminde üç tane GYO'nun piyasayı domine ettiği tespit edilmiştir. 2011-2018 döneminde ise iki tane GYO'nun piyasada \%10'dan daha fazla paya sahip olduğu tespit edilmiştir. Ancak bu dönemde $\mathrm{CR}_{4}$ yoğunlaşma oranına göre piyasa yoğunlaşmasında önemli düzeyde düşme olduğu ve piyasada oligopol bir piyasa yapısının geçerli olduğu tespit edilmiştir. GYO'ların $\mathrm{CR}_{4}$ yoğunlaşma oranına göre; 2007 yılında \%81,29 ile en yüksek değeri, 2018 yılında ise $\% 57,62$ ile en düşük değeri aldığı tespit edilmiştir.

CR\& yoğunlaşma endeksine göre; GYO sektöründe 2007-2018 döneminde çok yüksek piyasa yoğunlaşması, yani monopol bir piyasa yapısının olduğu tespit edilmiştir. Diğer yandan GYO'ların CR8 yoğunlaşma oranına göre; 2007 yılında \%96,00 ile en yüksek değeri, 2016 yılında ise \%73,11 ile en düşük değeri aldığı tespit edilmiştir.

HHI endeksine göre; GYO sektöründe çok yüksek piyasa yoğunlaşması olduğu, ancak 20122018 döneminde ise oligopol bir piyasa yapısının olduğu gözlenmiştir. Ayrıca GYO'ların yoğunlaşma düzeyi, HHI analiz sonucuna göre; 2010 yılında en yüksek endeks değerini 2297 ve 2018 yılında en düşük endeks değerini 1272 olarak aldığı tespit edilmiştir. 
2007 yılında 13 olan GYO sayısının 2010 yılında 21'e çıkmasıyla birlikte GYO'ların aktif varlıklarında artış olduğu ve beraberinde piyasada rekabet düzeyinin yükseldiği gözlenmiştir.

GYO'ların piyasa yapısı ve yoğunlaşma düzeylerinin belirlenmesi amacıyla 2007-2018 dönemi için yapılan ampirik analizlerden elde edilen sonuçlar ile Burucu \& Yıldız-Contuk (2016)'un bulguları arasında benzerlikler olduğu görülmüştür. Çalışmada daha fazla GYO'nun piyasa paylarını $\left(\mathrm{CR}_{8}\right)$ dikkate alarak sektördeki piyasa yapısı ve yoğunlaşma düzeylerinin belirlenmesi hedeflenmiştir. Bu yönüyle çalışma, Burucu \& Yıldız-Contuk (2016)'nın yaklaşımından farklılaşarak literatüre katkı sunmaktadır.

Çalışmadaki bulgular, veri seti ve kullanılan yöntemler nedeniyle sinırlılık içermektedir. Türkiye'deki GYO sektöründeki yoğunlaşma ve piyasa yapısının sektöre yeni GYO'ların girmesiyle rekabetin artması beklenmektedir. Bu sayede büyük gayrimenkul projelerinin hayata geçirilmesi ile ekonomik büyüme, istihdam artışı ve milli gelirin artmasına katkı sağlanabilecektir. GYO sayısının artması ve aktif değerlerinin büyümesi, banka dışı bir kurum olarak GYO'ların finans sektöründeki etkinliğinin artmasını sağlayacak ve küçük yatırımcıların daha fazla ilgisini çekebilecektir.

\section{Kaynakça}

Akan, Y. (2002). Türk imalat sanayinde yoğunlaşma: 1980-96, İktisat İşletme ve Finans, 17(198), 91-97.

Akgün-Güngör, G. (2014). Serbest ticaret ve endüstriyel yoğunlaşma ilişkisi: Türkiye imalat sanayi üzerine bir inceleme, Finans Politik \& Ekonomik Yorumlar, 51(595), 45-57.

Aktaş, E., \& Yurdakul, O. (2001). The analiysis of flour mill industry in Turkey, Munich: Munich Personal RePEc Archive. https://mpra.ub.uni-muenchen.de/4899/

Aytekin, S., \& Kahraman, E. (2015). BIST gayrimenkul yatırım ortaklıkları endeksindeki (XGMYO) şirketlerin finansal etkinliklerinin veri zarflama analizi yöntemi ile değerlendirilmesi, Niğde Üniversitesi İktisadi ve İdari Bilimler Fakültesi Dergisi, 8(1), 289-301. http://dergipark.ulakbim.gov.tr/niguiibfd/

Burucu, H., \& Yıldız-Contuk, F. (2016). Türk gayrimenkul yatırım ortaklıklarında rekabet yapısı, Finans Politik \& Ekonomik Yorumlar, 53(615), 89-100.

Çelik, Ş., \& Manan, M. T. (2018). Gayrimenkul yatırım ortaklıklarının risk ile performans ilişkisi, Muhasebe ve Finans İncelemeleri Dergisi, 1(1), 60-79. doi:https://doi.org/10.32951/mufider.385054

Dabara, D. I., Omotehinshe, O. J., Chiwuzie, A., Asa, O. A., \& Soladoye, J. O. (2018). The market structure of real estate investment trusts in Nigeria, Conference of the International Journal of Arts \& Sciences, 11(3), 101111.

Dalkılıç, B., \& Aşkın, M. (2018). Gayrimenkul ve konut sektörüne bakış. İstanbul: Dalfin Finansal ve Kurumsal Çözümler. http://www.emlakkonut.com.tr/ Assets/Upload/Images/file/Yatirimci/sektorRaporu/EKGYOSektor-Raporu-aralik-2018.pdf

Demirci, O. (2016). Türkiye'de iletişim sektöründe faaliyet gösteren mobil şirketleri piyasa yapısı, Ardahan Üniversitesi İktisadi ve İdari Bilimler Fakültesi Dergisi (3), 169-183.

Durukan, T., \& Hamurcu, Ç. (2009). Mobil iletişimde pazar yoğunlaşması: Türkiye ile Kazakistan, Kırgızistan, Tacikistan, Türkmenistan, Özbekistan karşılaştırması, Karadeniz Araştırmaları, 6(22), 75-86.

Ediz, Y., \& Önder, K. (2019). İçecek imalatı sektörünün piyasa yapısı ve yoğunlaşma düzeyi: Türkiye'nin ilk 1000 sanayi kuruluşu üzerine bir uygulama, Dumlupınar Üniversitesi Sosyal Bilimler Dergisi(60), 25-40. http://dergipark.gov.tr/dpusbe 
Erdogan, N. K., Altinirmak, S., \& Karamasa, C. (2016). Performance assessment of real estate investment trusts (REIT) listed in BIST via different multi criteria decision making METHODS, International Journal of Economics and Finance, 8(7), 304-321. doi:10.5539/ijef.v8n7p304

Gümüş, U. T., \& Çıbık, E. (2018). Borsa'da işlem gören gayrimenkul yatırım ortaklığı işletmelerinin birleşik oran analizi (Dupont) yöntemiyle performansının ölçülmesi, Hitit Üniversitesi Sosyal Bilimler Enstitüsü Dergisi, 11(3), 2178-2194. doi:10.17218/hititsosbil.421602

Günlü, A. (2011). Çiğ süt pazarlanmasında süt sanayi işletmelerinde firma yoğunlaşma oranlarının araştırılması: Burdur ili örneği, Kafkas Universitesi Veteriner Fakultesi Dergisi, 17(1), 101-106. doi:10.9775/kvfd.2010.2520

Hazar, A., Sunal, O., Babuşçu, Ş., \& Sezgin-Alp, Ö. (2017). Bankacılık sektöründe piyasa yoğunlaşması: 2001 krizi öncesi ve sonrasının karşılaştırılması, Maliye Finans Yazıları (107), 41-68.

Ildırar, M., \& Kıral, E. (2018). Piyasa yapısı ve yoğunlaşma: Türk otomotiv sektörü üzerine bir analiz, Abant İzzet Baysal Üniversitesi Sosyal Bilimler Enstitüsü Dergisi, 18(1), 93-117.

Ipek, E., \& Ipek, O. (2018). Market structure of the Turkish pharmaceutical industry , Business and Economics Research Journal, 9(3), 449-462. doi:10.20409/berj.2018.116

İslamoğlu, M., Apan, M., \& Öztel, A. (2015). An evaluation of the financial performance of REITs in Borsa Istanbul: A case study using the Entropy-based TOPSIS method, International Journal of Financial Research, 6(2), 124-138. doi:https://doi.org/10.5430/ijfr.v6n2p124

KAP (2019), Kamu Aydınlatma Platformu, www.kap.org.tr.

Kandır, S. Y., \& Özhan, E. (2018). Gayrimenkul yatırım ortaklığı pay getirilerini etkileyen faktörlerin araştırılması, BDDK Bankacılık ve Finansal Piyasalar, 12(2), 31-45. www.bddk.org.tr

Karakaya, A. (2017). Türkiye' deki gayrimenkul yatırım ortaklıklarının hisse senedi değeri ve süper etkinliği arasındaki ilişki, Anadolu İktisat ve İşletme Dergisi, 1(1), 1-17. https://dergipark.org.tr/anadoluiid

Kaynak, S. (2016a). Giyim eşyası imalatı piyasa yapısı ve yoğunlaşma oranı: Türkiye'nin ilk 500 sanayi kuruluşu üzerine bir uygulama, Uluslararası Yönetim İktisat ve İşletme Dergisi, 12(30), 21-37.

Kaynak, S. (2016b). Türk ilaç sektörünün rekabet yapısı ve yoğunlaşma analizi, Çankırı Karatekin Üniversitesi İktisadi ve İdari Bilimler Fakültesi Dergisi, 6(2), 49-66.

Kaynak, S., \& Arı, Y. O. (2011). Türk otomotiv sektöründe yoğunlaşma: Binek ve hafif ticari araçlar üzerine bir uygulama, Ekonomik Yaklaşım, 22(80), 39-58.

Koc, Y. D., Çelik, S., \& Arslan, S. (2017). Bankacılık sektörünün piyasa yapısı ve etkileri, Global Business Research Congress, 3, 143-152. doi:10.17261/Pressacademia.2017.400

Kostakoğlu, S. F. (2015). İnternet servis sağlayıcıları piyasasına yönelik yoğunlaşma analizi, Uluslararası Yönetim İktisat ve İşletme Dergisi, 11(25), 129-140. doi:http://dx.doi.org/10.17130/ijmeb.2015.11.25.875

Kösekahyaoğlu, L. (2007). Türkiye dış ticaretinde ürün ve ülke bazında yoğunlaşma: 1980-2005 dönemi üzerine karşılaştırmalı bir analiz. İstanbul Üniversitesi Siyasal Bilgiler Fakültesi Dergisi (36), 15-34.

Krstic, B., Radivojevic , V., \& Stanisic, T. (2016). Measuring market concentration in mobile telecommunication market in Serbia, Economics and Organization, 13(3), 247-260.

Matthes, F. C., Poetzsch, S., \& Grashoff, K. (2005). Power generation market concentration in Europe 1996-2004. An empirical analysis, Institute for Applied Ecology. Berlin: Öko-Institut e.V. www.oeko.de

Münyas, T. (2018). Gayrimenkul yatırım ortaklıklarının finansal etkinliklerinin veri zarflama analizi yöntemi ile değerlendirilmesi, Journal of Life Economic, 5(4), 111-126. doi:10.15637/jlecon.264

Önder, K. (2016). Türkiye bisküvi, çikolatalı ve şekerli mamuller sektörü: Firma yoğunlaşma analizi, Dokuz Eylül Üniversitesi İktisadi ve İdari Bilimler Fakültesi Dergisi, 31(2), 179-208. 


\section{Gayrimenkul Yatırım Ortaklıklarının Piyasa Yapısı ve Yoğunlaşma Düzeylerinin Analizi: Borsa İstanbul'dan Kanttlar}

Özbek, F. Ş., \& Fidan, H. (2016). Konya ilinde buğday üretiminde kullanılan tarım ilaçları piyasa yapısının belirlenmesi üzerine bir araştırma. Kahramanmaraş Sütçü İmam Üniversitesi Doğa Bilimleri Dergisi, 19(2), $147-151$.

Pehlivanoğlu, F., \& Tekçe, E. (2013). Türkiye elektrik enerjisi piyasasında Herfindahl- Hirschman ve CRm endeksleri ile yoğunlaşma analizi, Abant İzzet Baysal Üniversitesi Sosyal Bilimler Dergisi, 13(2), 363-385.

Pehlivanoğlu, F., \& Yavuz-Tiftikçigil, B. (2013). A concentration analysis in the Turkish iron-steel and metal industry, International Journal of Economic Practices and Theories, 3(3), 152-167. www.ijept.org

Polat, Ç. (2007). Yoğunlaşma ve piyasa yapısı ilişkisi çerçevesinde Türk çimento sektörünün yapısal analizi, Anadolu Üniversitesi Sosyal Bilimler Dergisi, 7(2), 97-116.

Pulaj-Brakaj, E., \& Kume, V. (2013). Measuring market concentration of construction industry. Vlora Region Evidence. European Scientific Journal, 9(32), 121-136.

Sarıbaş, H., \& Tekiner, İ. (2015). Türkiye sivil havacılık sektöründe yoğunlaşma, Finans Politik \& Ekonomik Yorumlar(52), 21-33.

SPK (2019), Sermaye Piyasası Kurumu, www.spk.gov.tr

Şahin, C. (2014). Firmaya özgü değişkenlerle gayrimenkul yatırım ortaklıkları (GYO) getirisi arasındaki ilişkiyi incelemeye yönelik bir uygulama. Dumlupınar Üniversitesi Sosyal Bilimler Dergisi(42), 11-18. https://dergipark.org.tr/dpusbe/issue/4784

Tatlı, H. (2018). Piyasa yoğunluğunun ölçülmesi: Beyaz eşya sektörü üzerine bir uygulama, Yönetim ve Ekonomi Araştırmaları Dergisi, 16(3 Özel Say1), 64-84. doi:http://dx.doi.org/10.11611/yead.441971

TÜiK (2015). Sanayi ve hizmet sektörlerinde yoğunlaşma, 2013, Haber Bülteni Sayı:18859, Tarih:28 Temmuz 2015. Türkiye İstatistik Kurumu. www.tuk.gov.tr/HbPrnt.do?d=18859

Yaşar, M., \& Kiracı, K. (2018). Dünya pazarlarında piyasa yapısı: Havayolu sektöründe rekabetin ampirik analizi. Uluslararası Yönetim İktisat ve İşletme Dergisi, 14(3), 731-744.

Yaşar, M., Kirac1, K., Kayhan, S., \& Ustaömer, T. C. (2017). A concentration analysis in the Turkish domestic air transportation industry using with $\mathrm{CRm}$ and Herfindahl-Hirschman indexes, Gaziantep University Journal of Social Sciences, 16(3), 687-704. doi:10.21547/jss.287910

Yayla, M. (2007). Türk bankacıllk sektöründe yoğunlaşma ve rekabet: 1995-2005, BDDK Bankacllık ve Finansal Piyasalar Dergisi, 1(1), 35-59.

Yetgin, F., \& İçten, O. (2018). TOPSIS yöntemi ile Borsa İstanbul'da işlem gören gayrimenkul yatırım ortaklıklarının 2007-2016 yılları arası finansal performans analizi, İstanbul Gelişim Üniversitesi Sosyal Bilimler Dergisi, 5(1), 19-44. doi:https://doi.org/10.17336/igusbd.388927

Yıldız, F. (2012). Türkiye'de mobil telekomünikasyon ve genişbant internet hizmetleri sektöründe pazar yoğunlaşmasının analizi, Süleyman Demirel Üniversitesi Vizyoner Dergisi, 3(6), 47-72.

Yılmaz, M. K., \& İçten, O. (2018). Borsa İstanbul'da işlem gören gayrimenkul yatııım ortaklıklarının nakit akımı odaklı finansal performans analizi (2007-2016). Finans Politik \& Ekonomik Yorumlar, 55(635), 73-87.

Yılmaz, N. K. (2019). Gayrimenkul yatırım ortaklıklarının finansal performansının TOPSís yöntemiyle ölçümü. BMIJ, 7(1), 423-443. doi:http://dx.doi.org/10.15295/bmij.v7i1.1080

Yılmaz-Türkmen, S. (2011). İMKB'de işlem gören gayrimenkul yatırım ortaklıklarının finansal etkinliklerinin veri zarflama analizi ile değerlendirilmesi, Marmara Üniversitesi İ.̇.B.F. Dergisi, 31(2), 273-288. https://dergipark.org.tr/muiibd/issue/498

Zügül, M., \& Şahin, C. (2015). Faiz oranı ve enflasyonun gayrimenkul yatırım ortaklığı getirisi üzerindeki etkisine yönelik bir uygulama, Akademik Bakı̧̧ Dergisi(49), 147-162. http://www.akademikbakis.org 